Studying The Effect of Cold Plasma on Living Tissues Using Images

Texture analysis

Sabah Noori Mazhir

\title{
Studying The Effect of Cold Plasma on Living Tissues Using Images Texture analysis
}

\author{
Sabah Noori Mazhir \\ Department of Physics- College of Science for Women- University of Baghdad
}

Received 5 June 2016 ; Accepted 18 September 2016

\begin{abstract}
$\underline{\text { Abstract }}$
The Direct exposure of the high-voltage (10-40 kV) with non-thermal plasma discharges in atmospheric air is utilized to heal living creatures. This process needs a high degree of safety. In this paper, the mice have been exposed to the cold plasma for different intervals of time from $20 \mathrm{sec}$. to $65 \mathrm{sec}$. The $1^{\text {st }}$ order and second order statistical feature were used to detect the changes which occur in the tissues, a comparison between the control and the wound part for all the using mice was achieved. This study shows that the tissues of mice have been changed in their structure when they are exposed to the cold plasma. This effect appeared from the light reflection from the skin. After 45 seconds exposure, the effect of the cold plasma appeared on the tissues. The best time of the skin wounds healing was at 65 seconds.
\end{abstract}

Keywords: Cold plasma, Needle plasma, Texture analysis, First order, Second order. 
دراسة تأثير البلازما الباردة على الأنسجة الحية باستخدام التحليل النسيجي للصور

$$
\begin{aligned}
& \text { صباح نوري مزهر } \\
& \text { قسم الفيزياء ـ كلية العلوم للبنات - جامعة بغداد }
\end{aligned}
$$

\begin{abstract}
الخلاصة
أن التطبيقات المباشرة لبلازما التفريغ الباردة ذات الفولتية العالية هي في معالجة الإنسان والحيو انات الحية والتي تتطلب نسبة أمان عالية . في هذا البحث تم تجريح و تعريض جلد الفئران للبلازما الباردة ولفترات مختلفة من 20 ثانية والى 65 ثانية. وتم استخدام تقنية الفحص النسيجي في تحليل الصور التي التقطت للجلد المعرض و الجلد غير المعرض. ونم تطبيق الطر ائق الإحصائية من المرتبة الأولى والمرتبة الثانية لحساب ستة معلمات للمرتبة الأولى وأربعة معلمات للمرتبة الثانية لغرض معرفة تأثير البلازما على جلد الفئر ان. وتبين من خلال النتائج ان الأنسجة المعرضة تتغير في صفات النسيج و هذا واضح من خلال انعكاس الضوء من النسيج، إذ تتغير ألوان النسيج بعد تعرضه للبلازما الباردة. وتبين إن تأثير البلازما

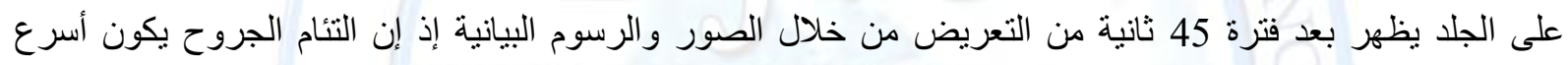
وخصوصا عند التعرض بـ 65 ثانية من النماذج الأخرى .

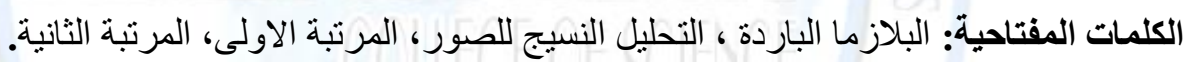

\title{
$\underline{\text { Introduction }}$
}

The plasma can be classified as the fourth state of the matter, it can be found in different types. It can also be prepared in different ways. The plasma can appear in two types: thermal and nonthermal plasma. These features give good indication about the cold plasma effect on the texture of mice skin. The use of cold plasma helps in effective medical treatments of various skin injuries and diseases, wounds, bacterial super infections, and fungal infections. Cold plasma can be defined as atmospheric air produced by electric discharge. The main features of cold plasma treatment can be described as a painless and contact-free procedure that is utilized to sterilize wounds and accelerate wound healing. The costs are comparable to or lower than those of standard antimicrobial wound treatment. For this purpose, a suitable plasma source was developed. Nowadays, many advanced and current researches have become applicable on clinical trials. [1-7]. 
Texture analysis

\section{Sabah Noori Mazhir}

\section{Medical Imaging:}

The Medical imaging can be defined as the process which gives information about interior of the human body. It can be used in the clinical analysis. The medical image processing tries to give information about the inter-structure such as skin, bones and cell blood; it also helps to diagnose the disease and give the right treatment.

\section{Thresholding:}

The thresholding method is one of the easiest methods used in segmentation process. The process partitioned the image into region one has all the pixels with a specific threshold and rejects the entire pixel below the suggested threshold. [8]

$$
\operatorname{img}(x, y)=\left\{\begin{array}{lll}
1 & \text { if } & \operatorname{img}(x, y) \geq T \\
0 & \text { if } & \operatorname{img}(x, y)<T
\end{array}\right\}
$$

Where $\operatorname{img}(\mathrm{x}, \mathrm{y})$ is the resulted image after thresholding.

\section{Density Slicing:}

Density Slicing represent the range of contiguous gray levels of a gray scale image by a single color. The range of contiguous gray levels is called a 'slice'. The gray scale range 0-255 is normally converted to several color slices. The conversion of a gray scale image to pseudo color is an effective way of highlighting different homogeneous areas in the image, it's important to specify a color for each current slice the boundaries of slice are obtained interactive process that allows adjusting different level until a satisfactory result has been achieved. A single band of a suitable image should be selected, loaded and displayed, and then the density slicing option was used to select grayscale slices and convert them to different colors as shown fig (1)[9]. The color density slicing change the gray levels value to color values in an image. The human eyes can distinguish about 16 levels of gray in an image, but it is able to distinguish between thousands of color hues. Thus, different enhancement technique is used to assign specific color to different digital value (DN). Increasing the value of the digital number contrast would change 
Studying The Effect of Cold Plasma on Living Tissues Using Images

Texture analysis

\section{Sabah Noori Mazhir}

the image from the gray scale to color. Density slicing is accomplished by arbitrarily dividing the range of brightness in a single band into intervals, then assigning each interval a color.

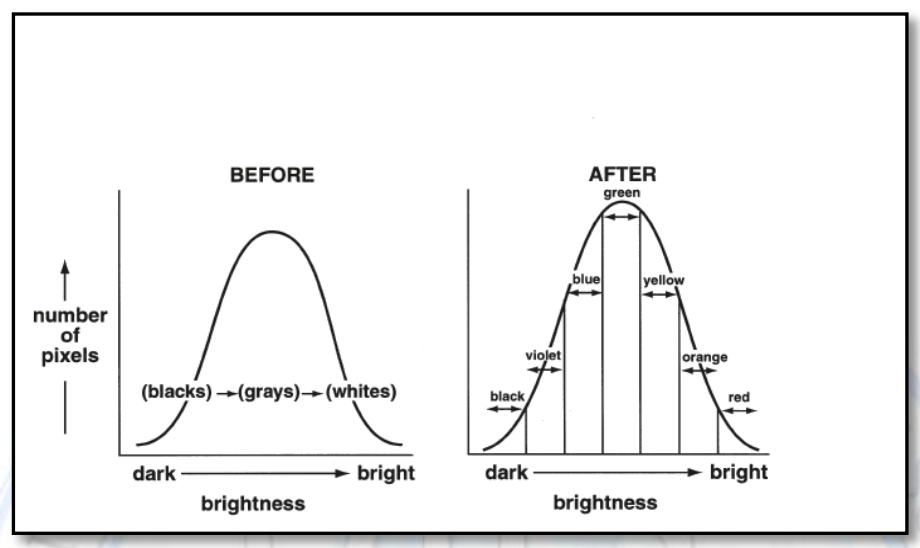

Figure (1) shows the Density slicing assigns colors to specific intervals of brightness values [9].

\section{First-Order Histogram features}

Standard deviation gives the measure of the average contrast, so the variance and standard deviation related to the mean. Energy gives indication about the number of gray level in the image tissue. Entropy represents the uniformity of the histogram and inversely proportional to the energy. Skewness tells the symmetries of the histogram around the mean. Kurtosis is the flatness of the histogram [10]. The image region can be represented by a random variable know as (i) the 1 st histogram $\mathrm{p}$ (i) can define $[11,12$, and 13]:

$$
\mathrm{p}(i)=\frac{\text { number of pixels with gray level } i}{\text { total number of pixel in the region }} .
$$

$\mathrm{P}(i)=\mathrm{H}(i) / \mathrm{NM}$

$\mathrm{P}(i)=$ is the probability of occurrence of the $i$. Where: $i=0,1,2 \ldots \ldots . \mathrm{G}-1$

$\mathrm{G}=$ gray level tone of an image (255), $\mathrm{N}=$ number of cells in the horizontal domain. 
Studying The Effect of Cold Plasma on Living Tissues Using Images

Texture analysis

\author{
Sabah Noori Mazhir
}

$\mathrm{M}=$ number of cell vertical domain

$$
\text { Mean: } \mu=\sum_{i=1}^{G-1} i p(i)
$$

$$
\begin{aligned}
& \text { Standard deviation: } \sigma=\sqrt{\sum_{i=0}^{G-1}(i-\mu)^{2} p(i)} \\
& \text { Energy: } E=\sum_{i-1}^{G-1}(p(i))^{2} \\
& \text { Entropy: } \mathrm{H}=-\sum_{i=1}^{G-1} p(i) \log 2[p(i)] \\
& \text { Variance: } \sigma^{2}=\sum_{i=1}^{G-1}(i-\mu)^{2} p(i) \\
& \text { Skewness: skew }=\sigma^{-3} \sum_{i=1}^{G-1}(i-\mu)^{3} p(i) \text {. } \\
& \text { Kurtosis: } k u r t=\sigma^{-} 4 \sum_{i-1}^{G-1}(i-\mu)^{4} p(i)
\end{aligned}
$$

The first order histogram needs to esteem (PDF) which is the probability density function for the neighborhood pixel. Different statistical features can be esteemed from the histogram which are Variance tells about the intensity variation around the mean [14].

\title{
The second order statistical
}

The second order statistical features which are co-occurrence texture features are computed from spatial gray dependence (SGLD) matrices. A SGLD matrix (P) contains the relative frequencies with which two pixels (one with gray level value $i$ and the other with gray level $j$ ) separated by distance $(d)$ with angle $(\theta)$ occurs in an image. The classification texture features depend on some criteria that can obtained from co-occurrence matrices.

\section{Contrast:}

Contrast is a natural measure of the degree of spread of the matrix values. Where $P(i, j)$ is the occurrence of pixel value in two dimension[15,16]. The contrast represented the variation in the pixel value (i.e.) variation in the No. of gray level 
Studying The Effect of Cold Plasma on Living Tissues Using Images

Texture analysis

\author{
Sabah Noori Mazhir
}

Contrast $=\sum_{i=0}^{N_{G^{-1}}} \sum_{j=0}^{N_{G}-1}(i-j)^{2} P(i, j) \ldots$

$P_{(i, j)}$ is the relative frequencies in two dimensions and $N_{G}$ represented the number of gray level.

2. Correlation:

Where:

Correlation $=\sum_{i=0}^{N_{G}}{ }^{-1} \sum_{j=0}^{N_{G}}{ }^{-1} \frac{P(i, j)\left(i-\mu_{x}\right)\left(j-\mu_{y}\right)}{\sigma_{x} \sigma_{y}}$

$$
\begin{aligned}
& \mu_{x}=\sum_{i=0}^{N} \sum_{j=0}^{-1} i \cdot P(i, j) \\
& \mu_{y}={ }_{i=0}^{N} \sum_{j=0}^{-1} j \cdot P(i, j)
\end{aligned}
$$

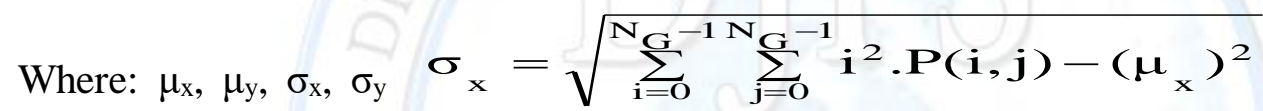

columns sum means $\sigma_{\mathbf{y}}=\sqrt{\sum_{\mathbf{i}=\mathbf{0}}^{\mathrm{N}} \sum_{\mathbf{j}=\mathbf{0}}^{-1} \mathrm{j}^{-1} \cdot \mathbf{P}(\mathbf{i}, \mathbf{j})-\left(\boldsymbol{\mu}_{\mathrm{y}}\right)^{2}}$ are the rows, and standard respectively. The correlation represented the higher connection between the pixels [16].

Homogeneity:

The value of the local homogeneity is high when the diagonal concentration is high. Homogeneity

$$
=\sum_{i=0}^{N_{G}^{-1}} \quad \sum_{j=0}^{N_{G}^{-1}} \frac{p(i, j)}{\left(1+(i-j)^{2}\right.} \ldots \ldots
$$

Energy:

$$
\text { Energy }=\sum_{i=0}^{N_{g}-1} \sum_{j=0}^{N_{g}-1}(P(i, j))^{2}
$$

To sum up, the variance value gives indication about the variation of the intensity of texture. The skewness measure is symmetric to mean value. The kurtosis is the flatness of the texture skin. Energy gives indication about the distribution of No. of gray level when the energy value is high this means that the skin is flat and there tissue is homogenous. The Entropy value is 
Studying The Effect of Cold Plasma on Living Tissues Using Images

Texture analysis

\author{
Sabah Noori Mazhir
}

inversely proportional to the energy. The contrast represented the variation in the pixel value (i.e.) variation in the No. of gray level the correlation represented the higher connection between the pixel, the Homogeneity represented the purity of the texture the purist texture the higher the value of Homogeneity

\title{
Materials and method
}

Non-thermal plasma which is so co-called plasma needle which is produced under atmospheric pressure by resources of radio-frequency excitation has been studied to reach the optimal aim of the paper which treating the fine surface of (bio) materials[17,18]. The needle plasma is generated by nitrogen, argon, helium, and mixtures of He with air. Electrical calculations show that needle plasma operates at moderately low voltages (200-500 V peak-to-peaks), and the power consumption ranges from tens of mile-watts to a few watts. The excitation, rotational and vibration of electron gives indication about the plasma temperatures, which can be measured by using optical emission spectroscopy. It is obvious that the temperatures can be measured in the range $(0.2-0.3 \mathrm{eV})$. The mice were exposed to the plasma for different interval of times starting from 20 to 65 seconds. The skin has been affected by the plasma which can be clearly shown by images token from the skin. The images were obtained by using the optical lenses microscope, which composed of a group of lenses. To reach the best resolution picture, the images were maximized 40 times. This microscope is connected to a computer that has a special program to capture a texture image of the mice skin. After obtaining the texture image, it was converted into gray scale to process them. Appling the segmentation process (which is the threshold), statistical features of the first and second order were calculated to study the effect of plasma on the texture. Figures (A to F) show the texture skin of the mice skin, the control and the exposure skin. Figures ( 2 to 8 ) show the distribution of statistical features, tables ( 1 to 4) show the statistical features value obtained from the first and second order. 
Texture analysis

\author{
Sabah Noori Mazhir
}

\begin{abstract}
Results and discussion
During the exposure to the cold plasma, the tissue showed changes in its structure. These changes appeared clearly after 45 to 65 seconds. The reflection of light showed different color than the other exposure sample. The sample that exposed to 65 seconds showed different of light. When the mean measure average value of intensity is high, the texture color tends to be whiter. If it is low, it tends to be black. From figure ( 2 to 7 ) one can see that value of contrast which is the separation of the pixel value is great when starting by 20sec. exposure and this value decreases when the time exposure increases this means that the cold plasma fasting the healing of the wounded skin this can clearly appear an time $65 \mathrm{sec}$., The correlation also increased when the time of exposure increased, this means that the wounded skin become in healing this lead to the high correlated also, energy increased as the time exposure increase this means that the texture of the skin have less no. of gray level and this indicate that the skin is in healing and the homogeneity increase in the time exposure $(65 \mathrm{sec})$. This give indication about the purity of the skin it means it become more pure that the control. Figures (8) show the statistical features for the first order the response also appear after $45 \mathrm{sec}$. the variance value decrease after exposure the mice skin to the cold plasma this means that the texture become more homogenous than control, also the energy increase this means the texture of the skin become more regular than the control part. The Kurtosis value increase with increasing time exposure this means that the histogram of the exposure skin become more flat than control and this give indication that the skin become more regular. The Entropy is inversely proportional to the energy and the skewnees doesn't give any indication about the texture of the skin also, does the mean, from these one can conclude that the cold plasma can be used to fasting the healing of wounded skin and it can be used in medical application and in the surge process. The density slicing shows that the reflection of the light from the texture change as the time of exposure increase.
\end{abstract}




\section{DIYALA JOURNAL FOR PURE SCIENCES}

Studying The Effect of Cold Plasma on Living Tissues Using Images

Texture analysis

\section{Sabah Noori Mazhir}

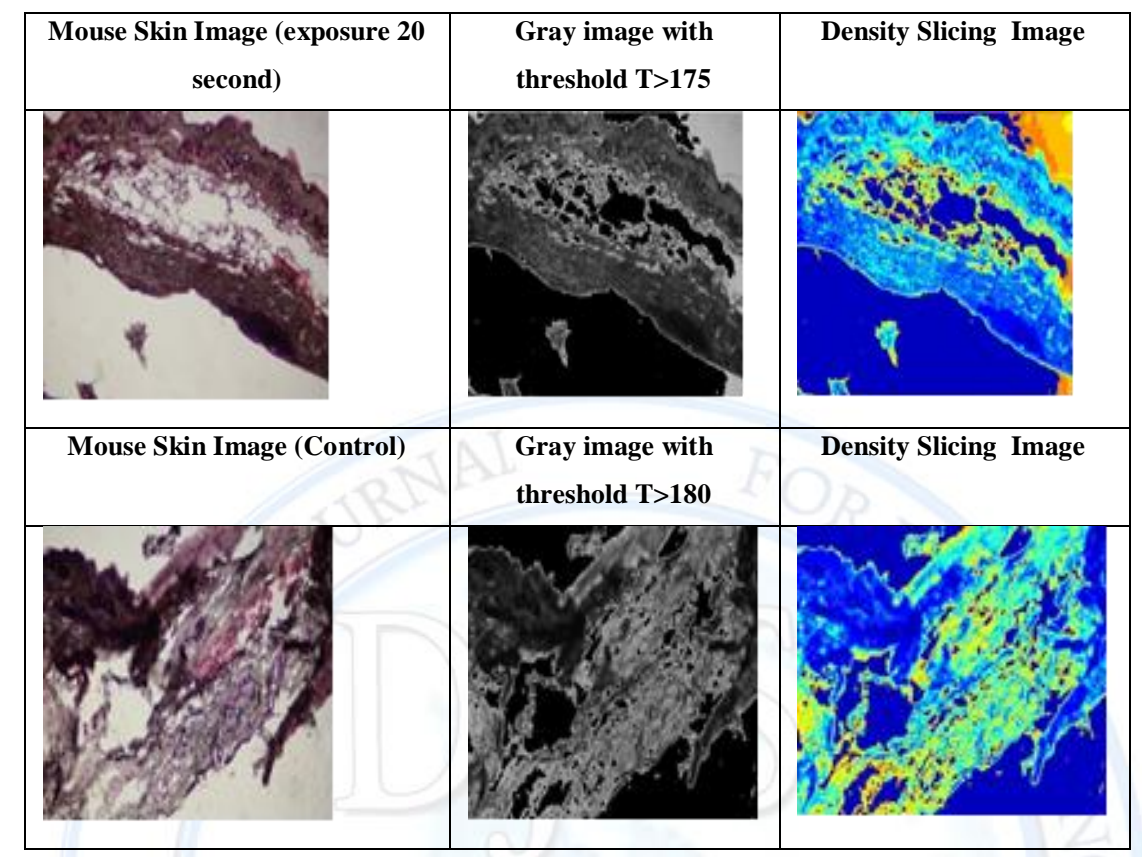

Figure (A) shows the Mouse skin images for 20 second time exposure and control Image.
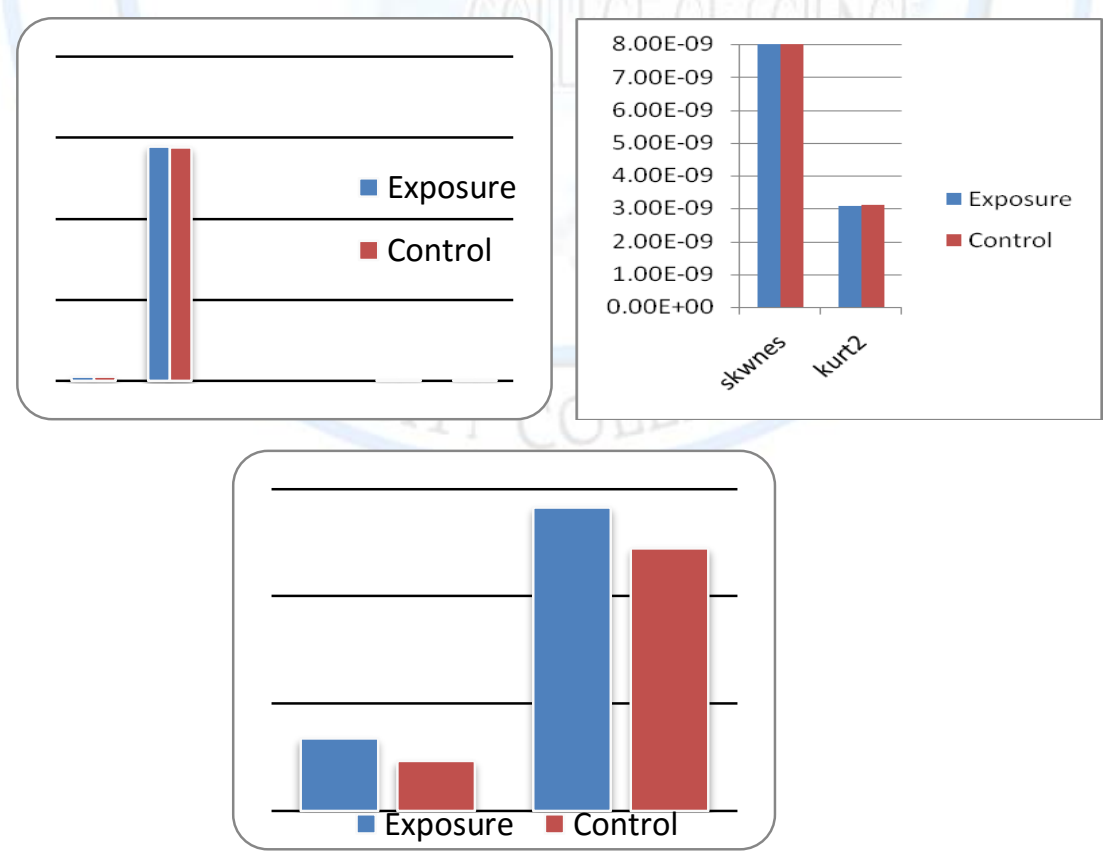

Figure(2) shows the statistical features for control and exposure skin for first order (20 second). 


\section{DIYALA JOURNAL FOR PURE SCIENCES}

Studying The Effect of Cold Plasma on Living Tissues Using Images

Texture analysis

\section{Sabah Noori Mazhir}

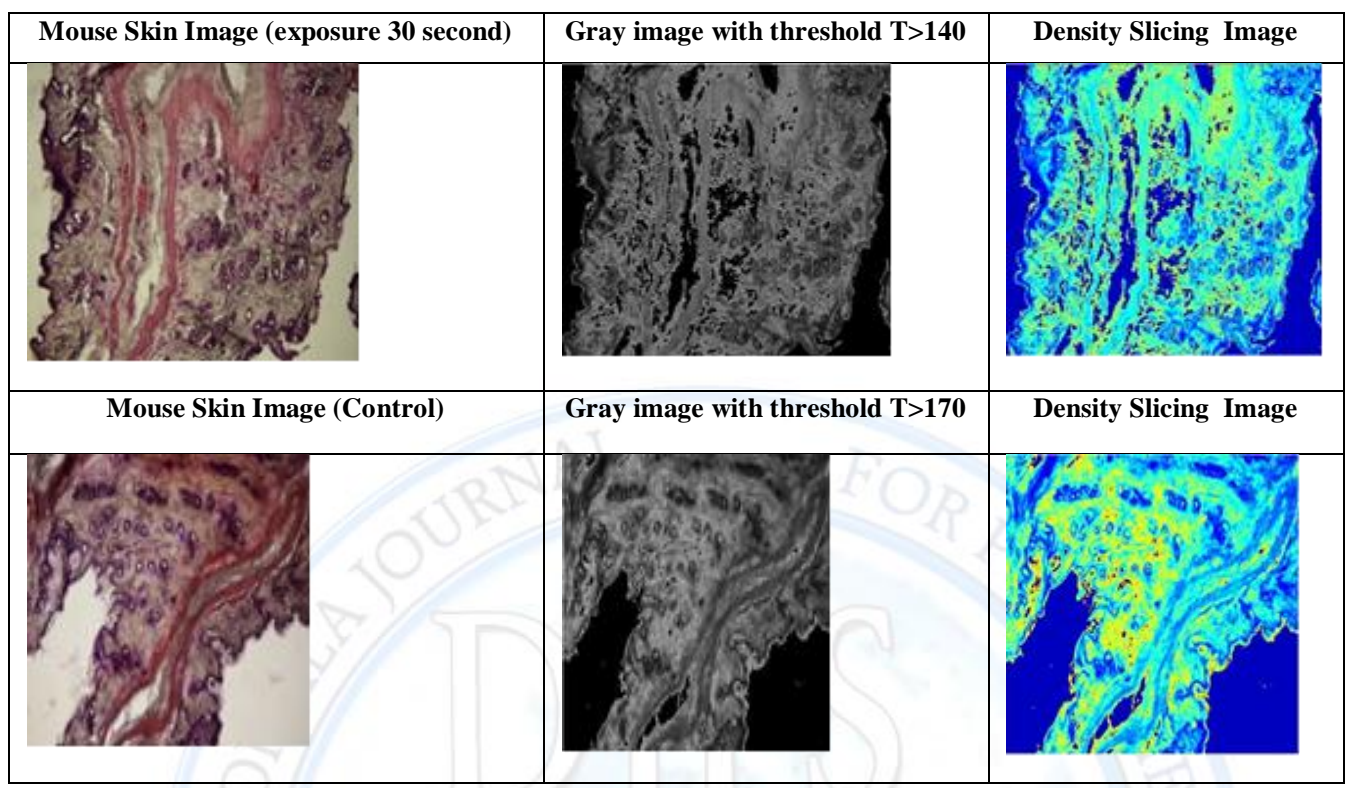

Figure (B) shows the Mouse skin images for 30 second time exposure and control Image

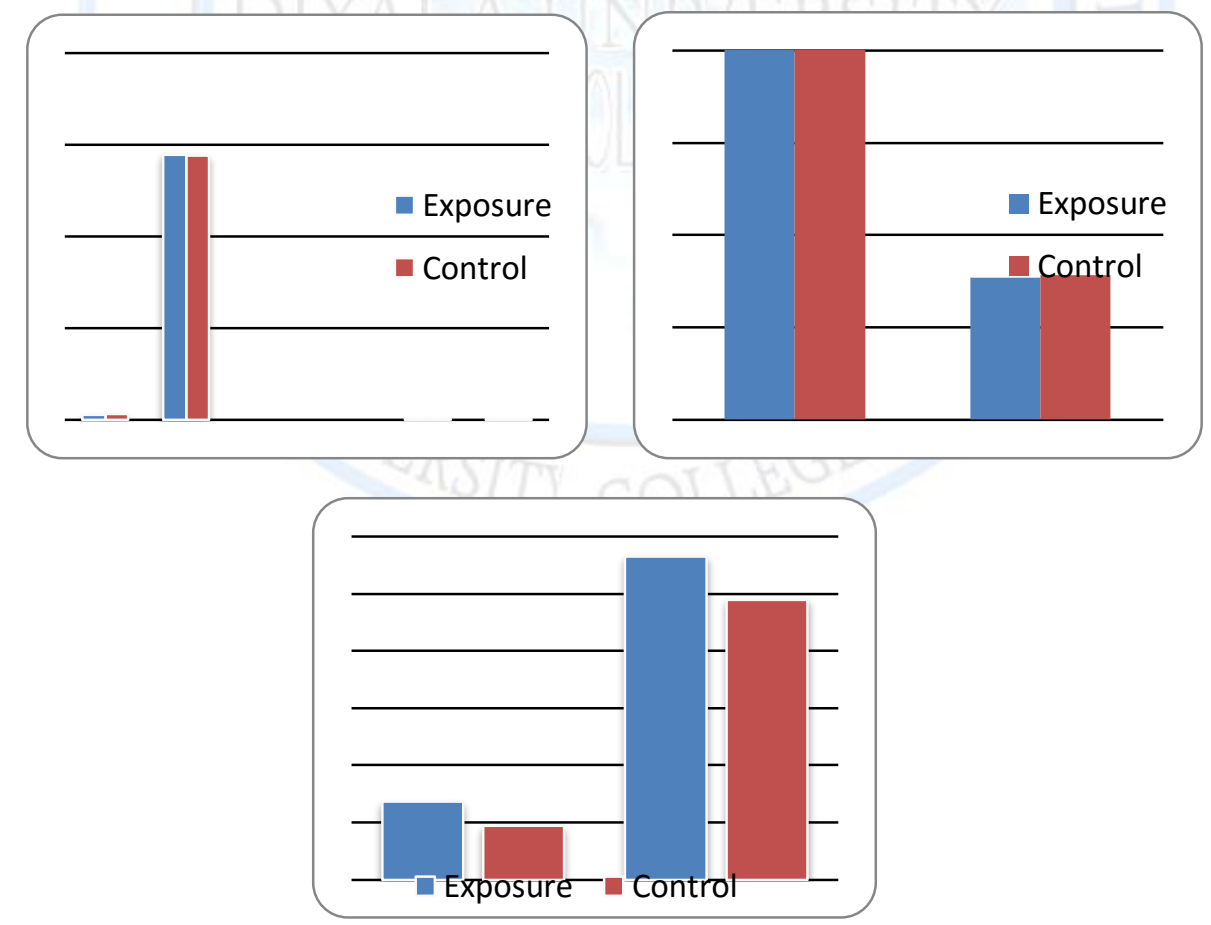

Figure (3) shows the statistical features for control and exposure skin for first order (30 second). 


\section{DIYALA JOURNAL FOR PURE SCIENCES}

Studying The Effect of Cold Plasma on Living Tissues Using Images

Texture analysis

\section{Sabah Noori Mazhir}

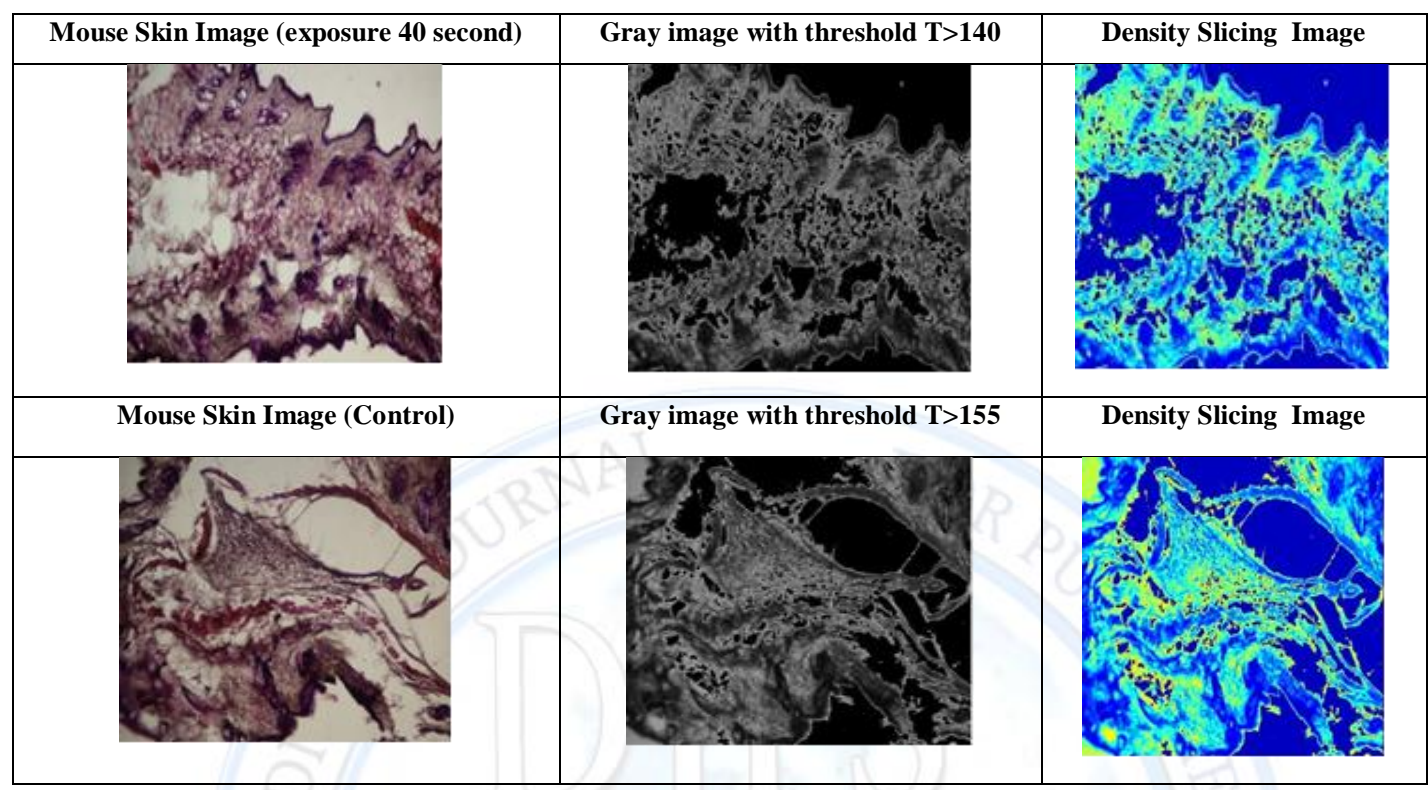

Figure (C) shows the Mouse skin images for 40 second time exposure and control Image

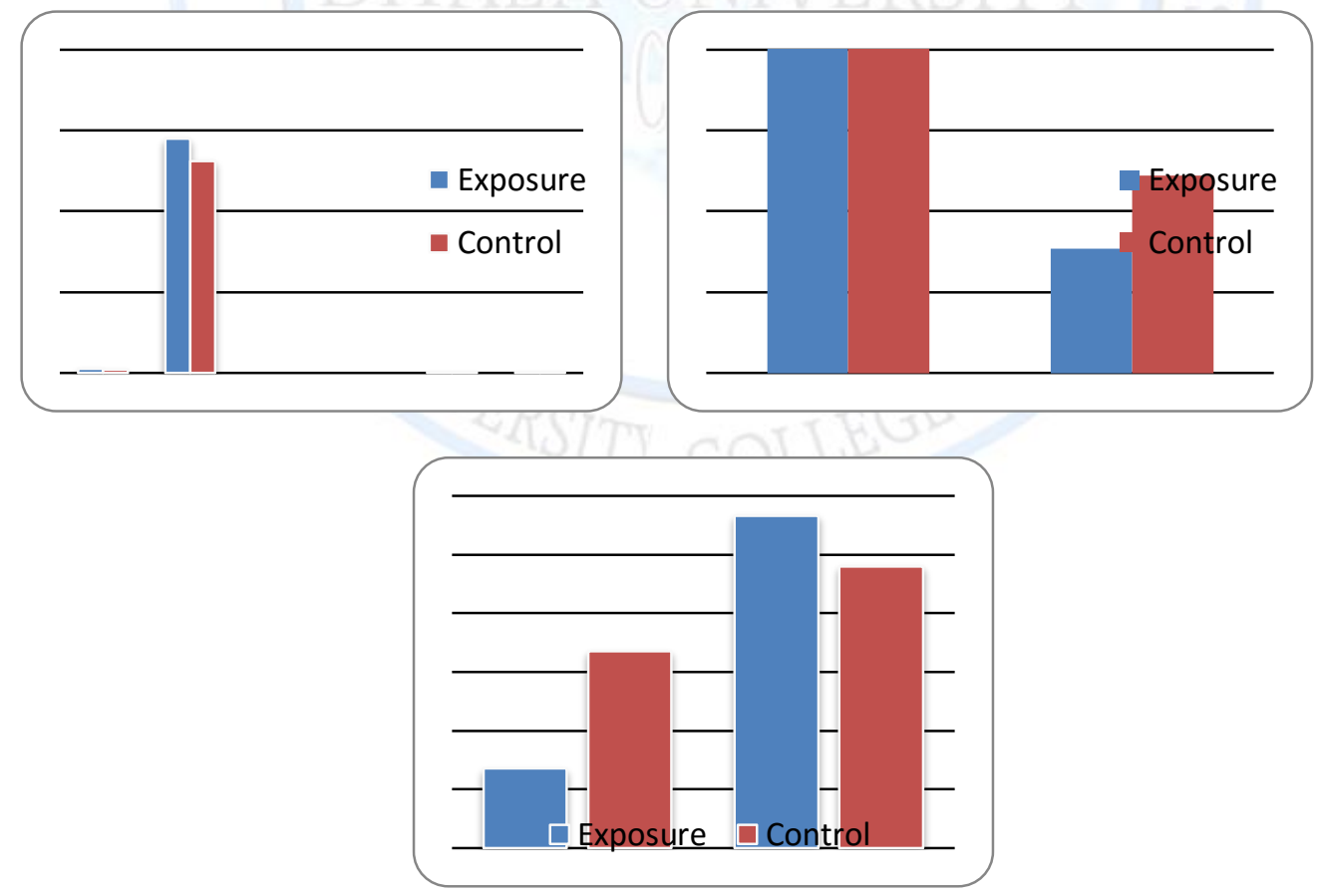

Figure(4) shows the statistical features for control and exposure skin for first order (40 second). 


\section{DIYALA JOURNAL FOR PURE SCIENCES}

Studying The Effect of Cold Plasma on Living Tissues Using Images

Texture analysis

\section{Sabah Noori Mazhir}

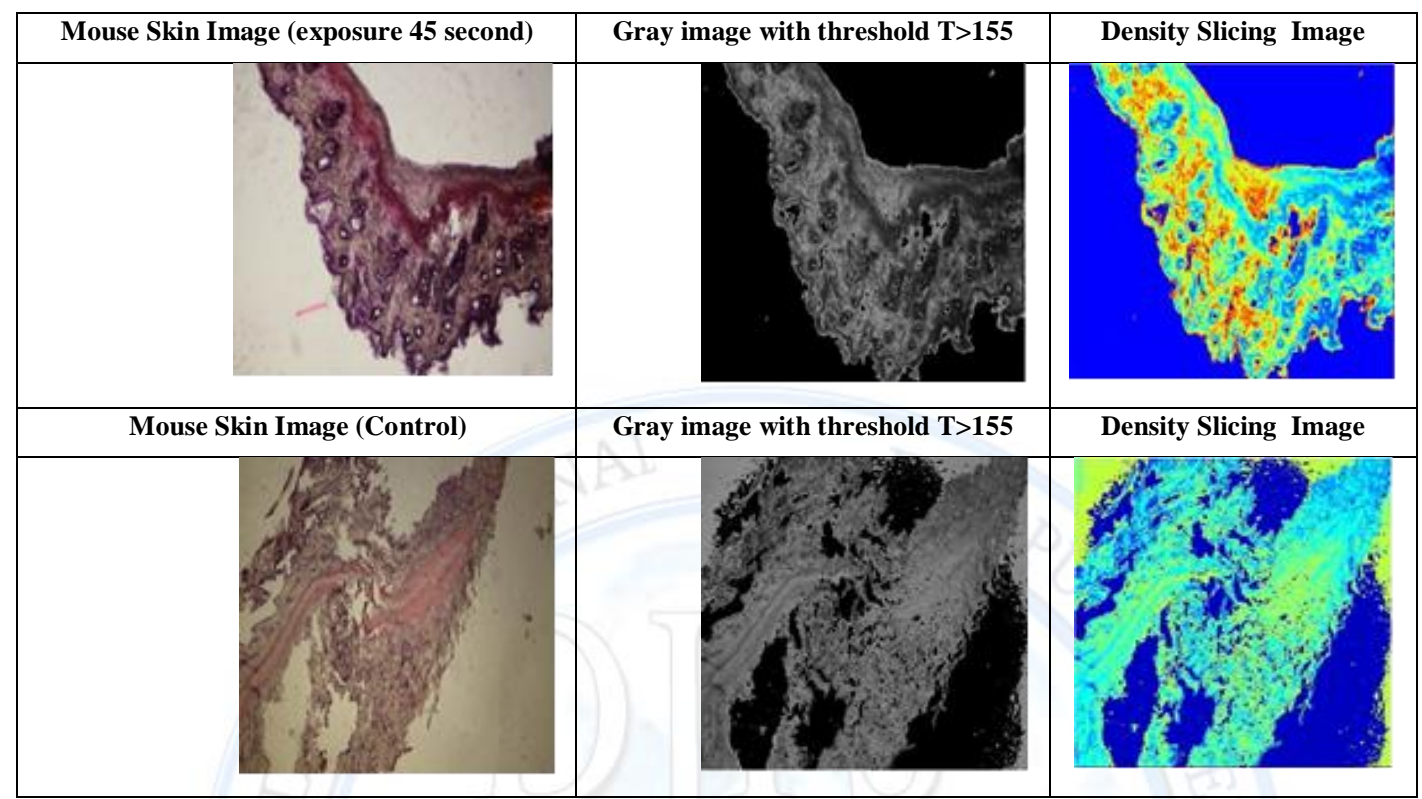

Figure (D) shows the Mouse skin images for 45 second time exposure and control Image
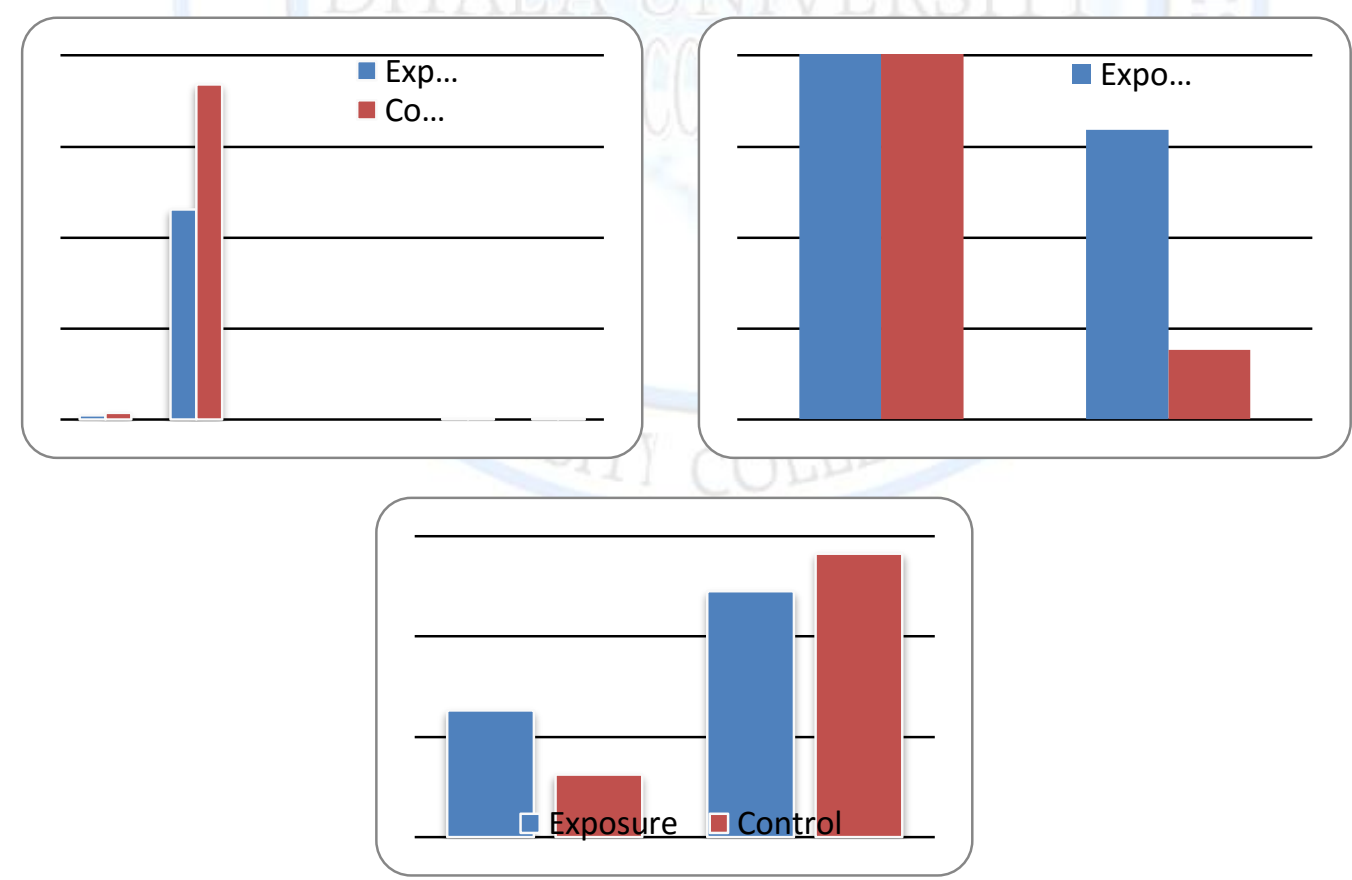

Figure (5) shows the statistical features for control and exposure skin for first order (45 second). 


\section{DIYALA JOURNAL FOR PURE SCIENCES}

Studying The Effect of Cold Plasma on Living Tissues Using Images

Texture analysis

\section{Sabah Noori Mazhir}

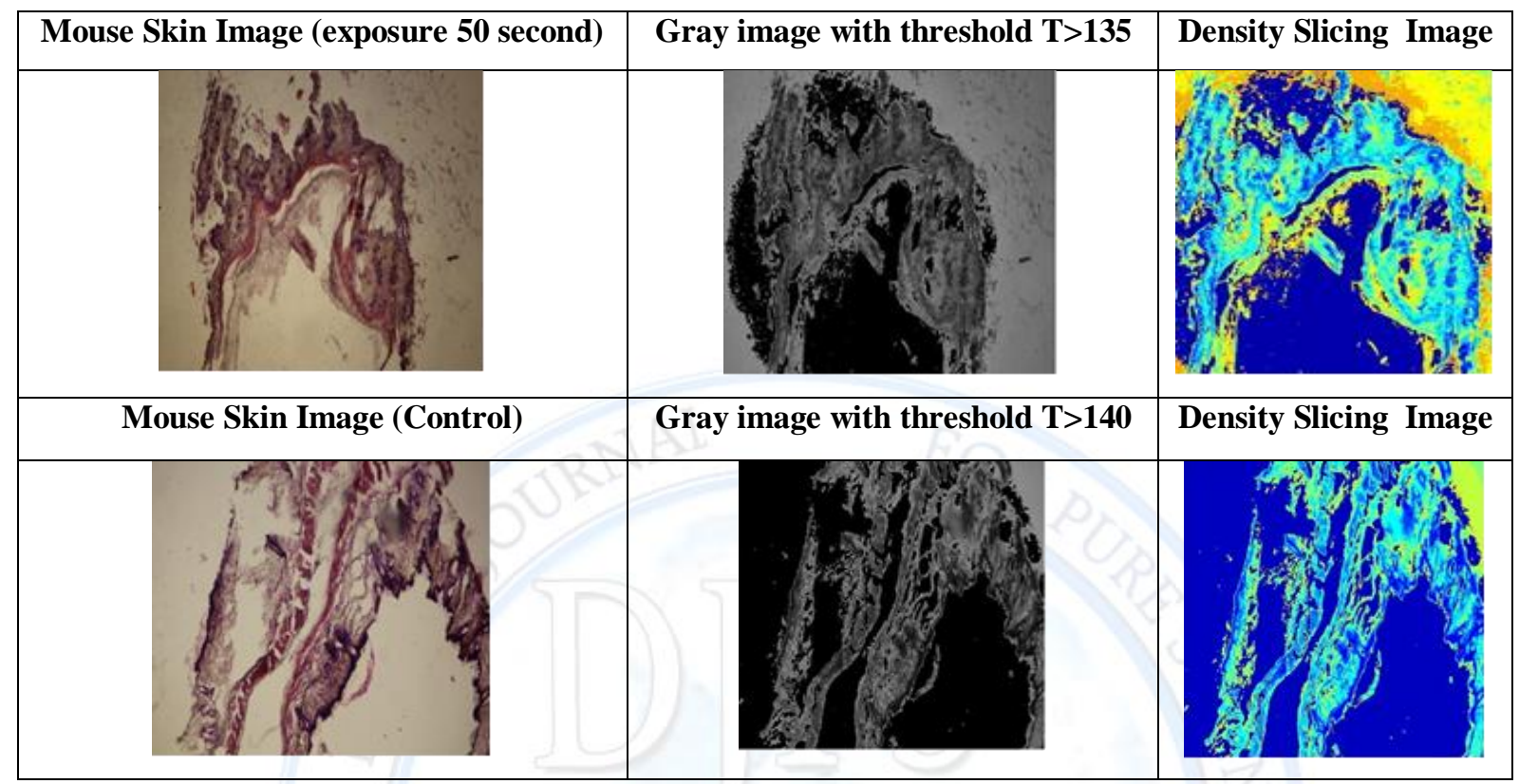

Figure (E) shows the Mouse skin images for 50 second time exposure and control Image

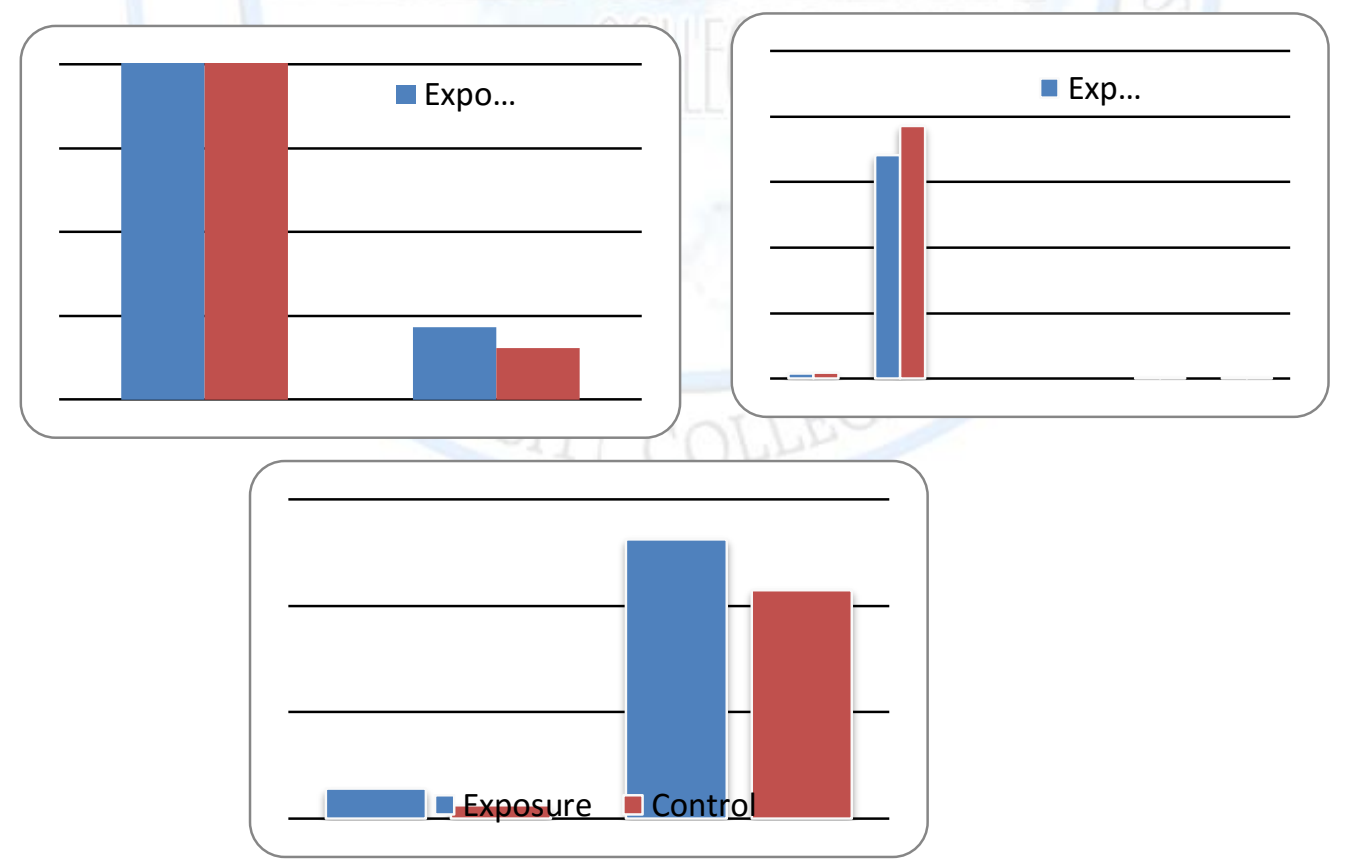

Figure(6) shows the statistical features for control and exposure skin for first order (50 second). 


\section{DIYALA JOURNAL FOR PURE SCIENCES}

Studying The Effect of Cold Plasma on Living Tissues Using Images

Texture analysis

\section{Sabah Noori Mazhir}

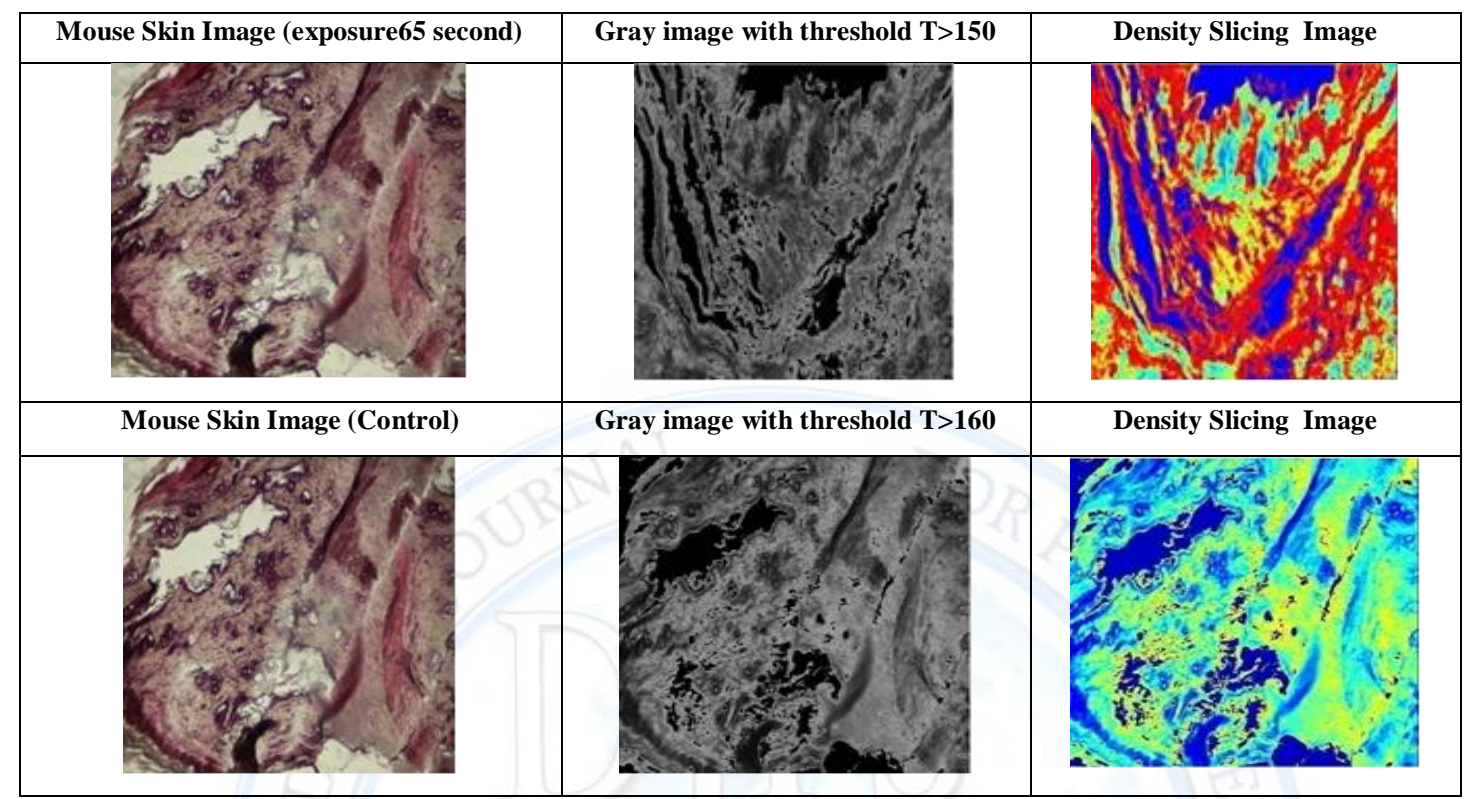

Figure (F) shows the Mouse skin images for 65 second time exposure and control Image.

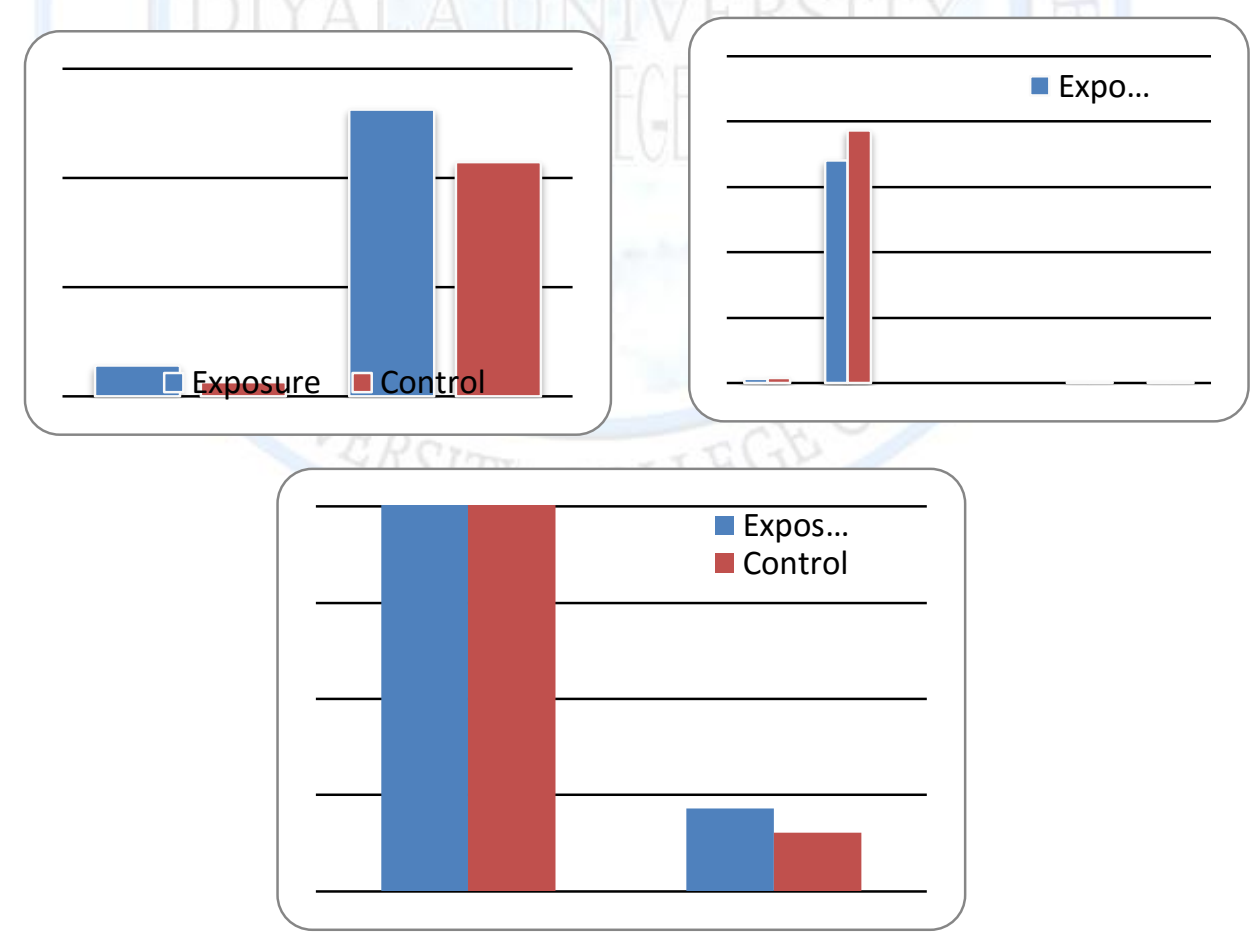

Figure(7) shows the statistical features for control and exposure skin for first order(65 second). 
Studying The Effect of Cold Plasma on Living Tissues Using Images Texture analysis

Sabah Noori Mazhir
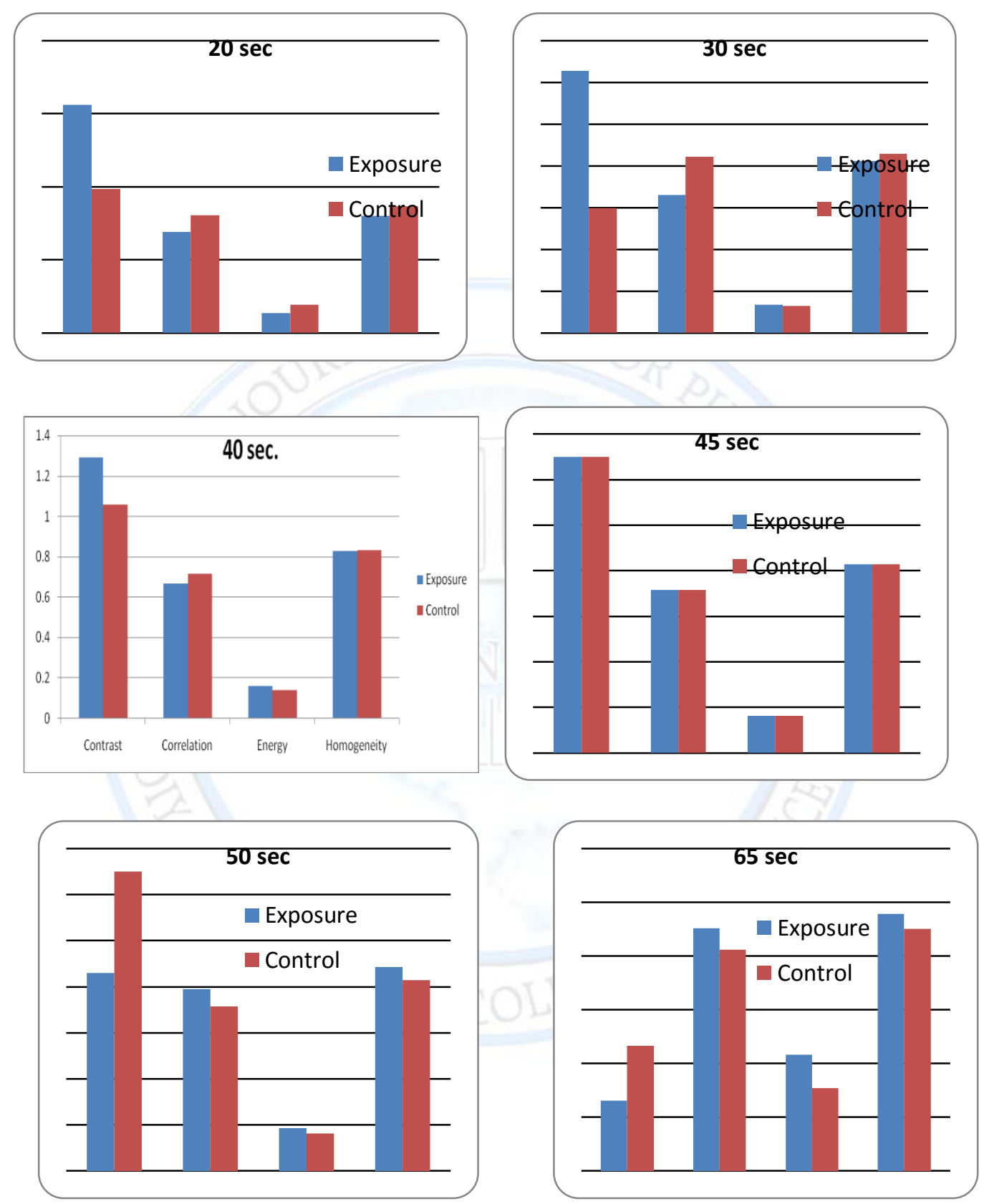

Figure (8) shows the statistical features for control and exposure skin for second order 
Studying The Effect of Cold Plasma on Living Tissues Using Images

Texture analysis

Sabah Noori Mazhir

Table (1) shows the first order statistical features for the images shown in exposre.

\begin{tabular}{|c|c|c|c|c|c|c|}
\hline & $20 \mathrm{~s}$ & $30 \mathrm{~s}$ & $40 \mathrm{~s}$ & $45 \mathrm{~s}$ & $50 \mathrm{~s}$ & $65 \mathrm{~s}$ \\
\hline Mean & $\mathbf{6 1 . 9 2 4 1}$ & $\mathbf{7 0 . 6 3 9 2}$ & $\mathbf{5 4 . 7 1 6 9}$ & $\mathbf{4 0 . 4 1 6 6}$ & $\mathbf{7 2 . 4 6 7 2}$ & $\mathbf{7 5 . 0 2 8 8}$ \\
\hline Variance & $\mathbf{3 . 7 5 0 4 e + 0 0 3}$ & $\mathbf{3 . 2 5 0 7 e + 0 0 3}$ & $\mathbf{2 . 8 9 3 6 e + 0 0 3}$ & $\mathbf{2 . 3 0 7 4 \mathrm { e } + 0 0 3}$ & $\mathbf{3 . 5 8 8 1 e + 0 0 3}$ & $\mathbf{3 . 4 1 0 6 e + 0 0 3}$ \\
\hline ske1 & $\mathbf{6 . 2 5 6 6 e - 0 0 6}$ & $\mathbf{6 . 4 7 0 1 e - 0 0 6}$ & $\mathbf{8 . 9 2 0 8 e - 0 0 6}$ & $\mathbf{1 . 4 6 8 5 e - 0 0 5}$ & $\mathbf{5 . 7 0 2 8 e - 0 0 6}$ & $\mathbf{5 . 8 7 2 3 e - 0 0 6}$ \\
\hline kurt2 & $\mathbf{1 . 6 6 8 2 e - 0 0 9}$ & $\mathbf{1 . 9 9 0 4 e - 0 0 9}$ & $\mathbf{3 . 0 8 3 0 e - 0 0 9}$ & $\mathbf{6 . 3 6 4 6 e - 0 0 9}$ & $\mathbf{1 . 5 8 9 3 e - 0 0 9}$ & $\mathbf{1 . 7 2 1 8 e - 0 0 9}$ \\
\hline Energy & $\mathbf{0 . 0 9 4 8}$ & $\mathbf{0 . 0 7 0 0}$ & $\mathbf{0 . 1 3 5 8}$ & $\mathbf{0 . 2 5 3 0}$ & $\mathbf{0 . 0 8 8 0}$ & $\mathbf{0 . 0 5 7 3}$ \\
\hline Entropy & $\mathbf{0 . 5 1 4 5}$ & $\mathbf{0 . 5 3 7 7}$ & $\mathbf{0 . 5 6 5 7}$ & $\mathbf{0 . 4 9 0 1}$ & $\mathbf{0 . 4 6 8 0}$ & $\mathbf{0 . 5 2 5 1}$ \\
\hline
\end{tabular}

Table (2) shows the first order statistical features for the images in control

\begin{tabular}{|c|c|c|c|c|c|c|}
\hline & $20 \mathrm{~s}$ & $30 \mathrm{~s}$ & $40 \mathrm{~s}$ & $45 \mathrm{~s}$ & $50 \mathrm{~s}$ & $65 \mathrm{~s}$ \\
\hline mean & $\mathbf{5 3 . 8 4 8 4}$ & $\mathbf{7 0 . 9 4 8 8}$ & $\mathbf{5 7 . 0 1 3 4}$ & $\mathbf{6 9 . 0 8 7 0}$ & $\mathbf{3 8 . 7 3 1 9}$ & $\mathbf{8 6 . 6 2 8 4}$ \\
\hline Variance & $\mathbf{3 . 5 2 5 0 \mathrm { e } + 0 0 3}$ & $\mathbf{3 . 3 2 5 9 e + 0 0 3}$ & $\mathbf{2 . 8 8 0 1 e + 0 0 3}$ & $\mathbf{3 . 6 7 8 4 e + 0 0 3}$ & $\mathbf{2 . 6 1 6 7 e + 0 0 3}$ & $\mathbf{3 . 8 5 8 6 e + 0 0 3}$ \\
\hline ske1 & $\mathbf{7 . 8 7 6 5 e - 0 0 6}$ & $\mathbf{6 . 3 6 9 0 e - 0 0 6}$ & $\mathbf{8 . 9 9 3 9 e - 0 0 6}$ & $\mathbf{5 . 6 1 8 7 e - 0 0 6}$ & $\mathbf{1 . 2 7 9 2 e - 0 0 5}$ & $\mathbf{4 . 6 9 1 7 e - 0 0 6}$ \\
\hline kurt2 & $\mathbf{2 . 2 3 4 4 e - 0 0 9}$ & $\mathbf{1 . 9 1 5 0 e - 0 0 9}$ & $\mathbf{3 . 1 2 2 8 e - 0 0 9}$ & $\mathbf{1 . 5 2 7 5 e - 0 0 9}$ & $\mathbf{4 . 8 8 8 6 e - 0 0 9}$ & $1.2159 \mathrm{e}-009$ \\
\hline Energy & $\mathbf{0 . 1 6 0 0}$ & $\mathbf{0 . 0 5 9 0}$ & $\mathbf{0 . 0 9 3 7}$ & $\mathbf{0 . 1 2 4 4}$ & $\mathbf{0 . 3 3 5 8}$ & $\mathbf{0 . 0 2 5 9}$ \\
\hline Entropy & $\mathbf{0 . 5 4 3 4}$ & $\mathbf{0 . 4 9 6 7}$ & $\mathbf{0 . 4 8 8 8}$ & $\mathbf{0 . 5 6 4 8}$ & $\mathbf{0 . 4 8 0 2}$ & $\mathbf{0 . 4 2 8 9}$ \\
\hline
\end{tabular}

Table (3) shows the second order statistical features for the images shown exposure.

\begin{tabular}{|c|c|c|c|c|c|c|}
\hline & $20 \mathrm{~s}$ & $30 \mathrm{~s}$ & $40 \mathrm{~s}$ & $45 \mathrm{~s}$ & $50 \mathrm{~s}$ & $65 \mathrm{~s}$ \\
\hline Contrast & 1.5605 & 1.2543 & 1.2922 & 1.3006 & $\mathbf{0 . 8 6 0 4}$ & $\mathbf{1 . 2 8 9 0}$ \\
\hline Correlation & $\mathbf{0 . 6 8 9 5}$ & $\mathbf{0 . 6 5 9 7}$ & $\mathbf{0 . 6 6 7 0}$ & $\mathbf{0 . 7 1 4 8}$ & $\mathbf{0 . 7 8 9 7}$ & $\mathbf{0 . 6 5 1 5}$ \\
\hline Energy & $\mathbf{0 . 1 3 5 2}$ & $\mathbf{0 . 1 3 5 9}$ & $\mathbf{0 . 1 5 9 2}$ & $\mathbf{0 . 1 6 3 3}$ & $\mathbf{0 . 1 8 5 8}$ & $\mathbf{0 . 1 2 7 5}$ \\
\hline Homogeneity & $\mathbf{0 . 7 9 9 5}$ & $\mathbf{0 . 8 2 2 2}$ & $\mathbf{0 . 8 2 7 3}$ & $\mathbf{0 . 8 2 9 4}$ & $\mathbf{0 . 8 8 6 4}$ & $\mathbf{0 . 8 2 8 2}$ \\
\hline
\end{tabular}


Studying The Effect of Cold Plasma on Living Tissues Using Images

Texture analysis

Sabah Noori Mazhir

Table (4) shows the second order statistical features for the images in control.

\begin{tabular}{|c|c|c|c|c|c|c|}
\hline & $20 \mathrm{~s}$ & $30 \mathrm{~s}$ & $40 \mathrm{~s}$ & $45 \mathrm{~s}$ & $50 \mathrm{~s}$ & $65 \mathrm{~s}$ \\
\hline Contrast & 0.9846 & 0.5973 & 1.0599 & 1.3006 & 1.3006 & 1.0913 \\
\hline Correlation & 0.8054 & 0.8427 & 0.7159 & 0.7148 & 0.7148 & 0.6950 \\
\hline Energy & 0.1945 & 0.1303 & 0.1399 & 0.1633 & 0.1633 & 0.1112 \\
\hline Homogeneity & 0.8683 & 0.8576 & 0.8344 & 0.8294 & 0.8294 & 0.8204 \\
\hline
\end{tabular}

\section{$\underline{\text { Conclusion }}$}

The conclusion can be illustrated follows:

1- From the results shown and from the tables we conclude that at the time 45 second the mouse tissue response to the plasma effect comparing this with the control part.

2- As the time of exposure increases the response of the texture increase and this is clearly appears in the result of the image and the result of the graphs.

3- The use of cold plasma in medical is a new technique for surgery treatment, since the cold plasma kills the Bactria. So, it helps to fasting the healing of wounds skin. This has been studying by use statistical features of texture skin.

4- As the time of exposure increase the texture of the wounded skin shows response to healing this can clearly shown from the result of statistical feature which obtained from the first order, second order, and the density slicing. 
Studying The Effect of Cold Plasma on Living Tissues Using Images

Texture analysis

\section{Sabah Noori Mazhir}

\section{$\underline{\text { References }}$}

1. Eliezer S. and Eliezer Y. (2001), The Fourth State of Matter-An Introduction to plasma Science, pp.5-7. Institute of Physics Publishing, Bristol and Philadelphia.

2. Fridman, A. Chirokov, and Gutsol A. (2005) Non-thermal atmospheric pressure discharges. J. Phys. D App. Phys. vol.38 No.(2), R1-R24.

3. Fridman G., Peddinghaus M., Ayan H., Fridman A., Balasubramanian M., Gutsol A.(2006) A. Brooks and G. Friedman, Blood coagulation and living tissue sterilization by floating-electrode dielectric barrier discharge in air, Plasma Chem. Plasma Process. vol: 26, No.4, pp.425-442.

4. Fridman G., Shekhter A.B., Vasilets V.N., Gutsol A., and Fridman A.,(2008) Plasma Medicine. Plasma Process. Polym. vol: 5, (6), pp.503-533.

5. Weltltmann K.-D., Woedtke TH. Von, Woedtke R. and Ehlbeck J. (2008), biomedical applications of atmospheric pressure plasma, Chem. Listy 102, s1450-s1451.

6. Sadiqali Ch., Mirko Č., Pavel S., Josef H.,(2010) Gas plasmas and plasma modified materials in medicine, J. Appl. Biomed vol:8 pp.55-66.

7. David B., Graves, 2014, Low temperature plasma biomedicine: A tutorial review, Physics of plasmas, 21, 080901

8. Rafael C., Gonzalez and Richard E. Woods, (2008) Digital Image Processing. $3^{\text {ed: }}$ Pearson Prentice Hall, New Jersey.

9. James B. Campbell, Randolph H. Wynne, (2011), Introduction to Remote Sensing, Fifth edition, the Guilford press.

10. Haralick R. M., Shanmugan K. and Dinstein I., (1973) "Textural Features for Image Classification" IEEE Transactions on Systems: Man, and Cybernetics SMC, vol. 3, pp. 610.

11. Ali H. A., Shahad I. A. Sabah N. Mazhir, (2015) Classification of Stroke Using Brain CT Digital Images, European academic research, vol. III, Issue 2 pp.2483-2489. 
Studying The Effect of Cold Plasma on Living Tissues Using Images

Texture analysis

\section{Sabah Noori Mazhir}

12. Hussain A., Mazher A.N. and A. Razak, (2012) "Classification of Breast Tissue for mammograms images using intensity histogram and statistical methods", A Refereed Science Journal issued by the college of science university of Baghdad, vol: 53, No.4.

13. Lingayat N. S. and Tarambale M. R., (2013)"A computer based feature extraction of lung Nodule in chest x-ray image", International journal of bioscience Biochemistry and bionionformatics, vol: 3, No.6.

14. Marwah A. A., Sabah N. Mazhir, Alyaa H. A. (2015) Detection and Segmentation of Lung Cancer using Statistical Features of X-Ray Images, IJCSMC, vol.4, Issue. 2, pp. $307-313$.

15. Gonzalez R. C. and Woods R. E., (2004) "Wavelet and Multiresolution Processing” In: Digital Image Processing, 2nd Edition, Pearson Education, Upper Saddle River, pp. 349-408.

16. Namita. A. and Agrawal R.K. (2012)," First and Second Order Statistics Features for Classification of Magnetic Resonance Brain Images", Journal of Signal and Information Processing, vol. 3, pp.146-153.

17. Park J, Henins I, Herrmann H W, Selwyn G S and Hicks R F, (2001) Discharge phenomena of an atmospheric pressure radio-frequency capacitive plasma source, $\mathrm{J}$. Appl. Phys. Vol.89 pp.20-28.

18. Spencer P. Kuo, (2012), Air plasma for medical applications, J. Biomedical Science and Engineering, Vol.5, pp.481-495. 